\title{
PENERAPAN SUPERVISI AKADEMIK UNTUK MENINGKATKAN KOMPETENSI GURU DALAM MENYUSUN ADMINISTRASI PENILAIAN DI UPTD SDN TAMBERU TIMUR KECAMATAN SOKOBANAH KABUPATEN SAMPANG
}

\author{
Hodden \\ Kepala UPTD SDN Tamberu Timur \\ Hodden123@gmail.com
}

\begin{abstract}
Abstrak
Tujuan penelitian tindakan kepala sekolah ini adalah untuk meningkatkan kompetensi pedagogik guru-guru di UPTD SDN Tamberu Timur kecamatan Sokobanah kabupaten Sampang dalam menyusun administrasi penilaian melalui supervisi akademik. Jenis penelitian yang digunakan dalam penelitian ini adalah penelitian tindakan sekolah. Kegiatan dalam penelitian ini terdiri atas tahapan perencanaan tindakan, pelaksanaan tindakan, observasi, dan refleksi.Teknik pengumpulan data menggunakan teknik obeservasi kelas.Instrumen observasi yang digunakan adalah alat penilaian kemampuan guru (APKG) berupa Instrument penilaianadministrasi pembelajaran. Analisis data yang digunakan adalah teknik analisis deskriptif komparatif. Data kuantitatif yang diperoleh di deskripsikan dalam bentuk kata-kata atau penjelasan. Selanjutkan dilakukan komparasi data untuk memastikan ada tidaknya peningkatan kemampuan guru dalam penilaian administrasi pembelajaran. Hasil penelitian menunjukkan temuan bahwa supervisi akademik dapat meningkatkan kemampuan guru-guru dalam menyusun administrasi penilaian dalam pembelajaran di UPTD SDN Tamberu Timur kecamatan Sokobanah kabupaten Sampang sebesar26,2\%.
\end{abstract}

\section{Kata Kunci: Supervisi Akademik, Kompetensi Pedagogik}

\begin{abstract}
The aim of the principal's action research was to improve the pedagogical competence of teachers in the UPTD SDN Tamberu Timur, Sokobanah subdistrict, Sampang district in preparing administrative assessments through academic supervision. This type of research used in this research is school action research. The activities in this study consisted of the stages of action planning, action implementation, observation, and reflection. Data collection techniques used classroom observation techniques. The observation instrument used was a teacher ability assessment tool (APKG) in the form of a learning administration assessment instrument. The data analysis used was a comparative descriptive analysis
\end{abstract}


technique. The quantitative data obtained are described in the form of words or explanations. Continued data comparisons to ensure whether there is an increase in the ability of teachers in learning administration assessment. The results showed the findings that academic supervision can improve the ability of teachers in compiling administrative assessments in learning at the UPTD SDN Tamberu Timur, Sokobanah sub-district, Sampang district by $26.2 \%$.

Keywords: academic supervision, pedagogic competence

Keywords: Academic Supervision, Pedagogic Competence

\section{PENDAHULUAN}

Pendidikan adalah salah satu upaya yang dilakukan untuk memperbaiki sumber daya manusia. Salah satu upaya yang dilakukan untuk memperbaiki sumber daya manusia adalah dengan memperbaiki proses pembelajaran di sekolah. Dalam meningkatkan kualitas sumberdaya manusia, guru mempunyai peran yang sangat penting. Keberhasilan siswa dalam belajar sangat dipengaruhi oleh bagaimana cara guru mengajar. Guru tidak hanya berfungsi mentransfer pengetahuan saja tetapi juga bertugas untuk memberikan keterampilan, merubah perilaku peserta didik. Untuk itu diperlukan guru yang profesional dalam pendidikan. Oleh karena itu kompetensi guru harus terus menerus dibina dan dikembangkan sehingga guru mampu menghasilkan pendidikan yang bermutu.

Undang-Undang Nomor 14 Tahun 2005 tentang Guru dan Dosen mengemukakan bahwa seorang guru adalah pendidik profesional dengan tugas utama mendidik, mengajar, membimbing, mengarahkan, melatih, menilai, dan mengevaluasi peserta didik pada jalur pendidikan formal, pendidikan dasar, dan pendidikan menengah. Dalam

Permendiknas No. 16 Tahun2007 menyebutkan kompetensi guru SD/MI antara lain: 1) memahami prinsip-prinsip penilaian dan evaluasi proses dan hasil belajar sesuai dengan karakteristik lima mata pelajaran SD/MI; 2)menentukan aspek-aspek proses dan hasil belajar yang penting untuk dinilai dan dievaluasi sesuai dengan karakteristik lima mata pelajaran SD/MI; 3) menentukan prosedur penilaian dan evaluasi proses dan hasil belajar; 4) mengembangkan instrumen penilaian dan evaluasi proses dan hasil belajar; 5) mengadministrasikan penilaian proses dan hasil belajar secara berkesinambungan dengan mengunakan berbagai instrumen;6) menganalisis hasil penilaian proses dan hasil belajar untuk berbagai tujuan; 7) melakukan evaluasi proses dan hasilbelajar.

Namun kenyataan dilapangan masih jauh dari harapan atau belum sepenuhnya komponen itu dilaksanakan. Hasil wawancara dengan kepala sekolah UPTD SDN 
Tamberu Timur (Pujiono) menunjukkan bahwa guru masih belum kompeten dalam menyusun administrasi penilaian pembelajarandengan baik. Hal ini ditunjukkan: 1) Ada 3 guru $(23 \%)$ yang berada pada skor kurang dari 51-60\% atau kategori kurang. Guru belum melaksanakan penilaian afektif, belum melaksanakan tugas secara tertruktur, belum melaksanakan program dan pelaksanaan remidial serta belum melakukan analisis hasil ulangan; 2) Ada 5 guru $(38,5 \%)$ yang berada pada skor $55-70 \%$ atau kategori cukup. menunjukkan guru belum membuat program dan pelaksanaan remidial, belum melakukan analisis hasil ulangan serta belum membuat instrumen tes dan bank soal; 3) Ada 5 guru(38,5\%) yang berada pada skor $71-85 \%$ atau kategori Baik. Berdasarkan kondisi seperti telah dipaparkan diatas, maka kepala sekolah berupaya melakukan perbaikan dalam rangka peningkatan kompetensi pedagogik menggunakan supervisiakademik.

Menurut Arikunto Suharsimi (2006:5) kegiatan supervisi ada dua jenis yaitu supervisi akademik dan supervisi administrasi.Dari dua kegiatan supervisi yang ada, supervisi akademik merupakan kegiatan yang sangat potensial untuk meningkatkan kompetensi pedagogik guru .Potensi supervisi akademik tersebut oleh karena lingkupnya langsung pada kegiatan pembelajaran.Sedangan yang menjadi focus dalam supervisi akademik adalah mengkaji, menilai,memperbaiki, meningkatkan, dan mengembangkan mutu kegiatan belajar mengajar yang dilakukan guru melalui pendekatan bimbingan dan konsultasi dalam nuansa dialog profesional.

Berdasarkan latar belakang seperti tersebut di atas, permasalahan penelitian yang akan dipecahkan adalah apakah supervisi akademik dapat meningkakan kompetensi pedagogik guru SD dan bagaimana supervisi akademik dapat meningkatkan kompetensi pedagogik guru SD.

\section{METODE}

Penelitian ini merupakan penelitian tindakan sekolah (PTS) yang dilakukan di UPTD SDN Tamberu Timur kecamatan Sokobanah kabupaten Sampang Semester 1 Tahun Pelajaran 2018/2019. Pelaksanaan penelitian tindakan sekolah ini dilakukan melalui tahapan penyusunan proposal penelitian, penyusunan instrument, pelaksanaan tindakan dalam rangka pengumpulan data, analisis data dan pembahasan hasil penelitian serta penyusunan laporan PTS. Subyek yang dilibatkan dalam penelitian tindakan sekolah ini adalah guru kelas VI.Sumber data primer berasal dari hasil pengukuran variabel penelitian tindakan sekolah berikut skor kemampuan guru menyusun administrasi penilaian pembelajaran.

Teknik pengumpulan data menggunakan teknik obeservasi kelas. Instrumen observasi yang digunakan adalah alat penilaian kemampuan guru (APKG) berupa: Instrument penilaian administrasi pembelajaran dan kisi-kisi instrumen pengukuran. Instrument penilaian administrasi pembelajaran. mencakup 10 komponen, yaitu: (1) Buku 
nilai/Daftar nilai, (2) Pelaksaan Tes (kognitif): UH, UTS, UAS, (3) Penugasan terstruktur (PT), (4) Kegiatan mandiri tidak terstruktur (KMTT), (5) Pelaksanaan penilaian ketrampilan (psikomotor), (6) Pelaksanaan penilaian Afektif akhlak mulia,(7) Pelaksanan penilaian Afektif kepribadian, (8) Program dan pelaksanaan Remidial,(9) Analisis hasil ulangan, (10) Bank Soal/Instrumen Tes. Kisi-kisi instrumen kemampuan guru dalam melakukan penilaian administrasi pembelajaran mencakup10 komponen yaitu: (1) Buku nilai/Daftar nilai (item no 1), (2) Pelaksaan Tes (kognitif): UH, UTS, UAS (item no 2), (3) Penugasan terstruktur (PT) (item no 3), (4) Kegiatan mandiri tidak terstruktur (KMTT) (item no 4), (5) Pelaksanaan penilaian ketrampilan (psikomotor) (item no 5), (6) Pelaksanaan penilaian Afektif akhlak mulia (item no 6), (7) Pelaksanan penilaian Afektif kepribadian (item no 7), (8) Program dan pelaksanaan Remidial (item no 8),(9) Analisis hasil ulangan (item no 9), (10) Bank Soal/Instrumen Tes (item no 10).

Tiap instrumen penilaian terdapat 5 kualifikasi penilaian yaitu 1, 2, 3, 4 dan 5 Setiap skor yang diperoleh kemudian dibagi dengan skor maksimal dan dikalikan dengan 100atau $\mathrm{N}=\frac{\text { skoryangdiperoleh }}{\text { skor maksimal }} \times 100$ Adapun kriteria penilaian yaitu: Baik

Sekali berada di skor 91 sampai 100, Baik berada pada skor 76 sampai 90, Cukup berada pada skor 61 sampai 75, Kurang berada pada skor 51 sampai 60 sedangkan Kurang Sekali berada pada skor kurang dari 50.

Analisis data yang digunakan adalah teknik analisis deskriptif komparatif. Data kuantitatif yang diperoleh di deskripsikan dalam bentuk kata-kata atau penjelasan.Selanjutkan dilakukan komparasi data untuk memastikan ada tidaknya peningkatan kemampuan guru dalam menyusun perencanaan pembelajaran, peningkatan kemampuan guru dalampelaksanaan.

Sebagai tolok ukur keberhasilan pelaksanaan penelitian tindakan kelas ini ditetapkan indikator kinerja sebagi berikut: 1) Persentase jumlah skor perolehan kemampuan administrasi penilaian pembelajaran sebesar $25 \%$. 


\section{HASIL PENELITIAN DAN PEMBAHASAN}

Hasil tindakan supervisi memberikan gambaran peningkatan penyusunan administrasi penilaian pembelajaran. Skor capaian hasil penyusunan administrasi penilaian pembelajaran tersebut dirangkum dalam Tabel 1.

Tabel 1 Komparasi Tingkat kompetensi Penyusunan Administrasi Penilaian Pembelajaran

\begin{tabular}{|c|c|c|}
\hline \multirow{2}{*}{ Pembelajaran } & \multicolumn{2}{|c|}{$\begin{array}{c}\text { Tingkat Kompetensi penyusunan } \\
\text { administrasi penilaian pembelajaran }\end{array}$} \\
\cline { 2 - 3 } & Mean & \% Kenaikan \\
\hline KondisiAwal & 63,5 & - \\
\hline Tindakan & 89,6 & 26,2 \\
\hline
\end{tabular}

Dari data dalam Tabel 1 diatas, diperoleh temuan: a) pada kondisi awal, rata-rata tingkat kompetensi penyusunan administrasi penilaian pembelajaranbaru mencapai 63,5 (skor maksimal ideal 100); b) setelah diberikan tindakan, rata-rata kompetensi penyusunan administrasi penilaian pembelajaran mencapai 89,6. Data ini menunjukkan peningkatan kompetensi penyusunan administrasi penilaian pembelajaran sebesar $26,2 \%$.

Tabel 2 berikut memberikan gambaran distribusi dan visualisasi skor kondisi awal dan setelah diberi tindakan.

Tabel 2

Distribusi FrekuensiTingkat Kompetensi Penyusunan Administrasi Penilaian Pembelajaran Kondisi Awal dan setelah Tindakan

\begin{tabular}{|l|c|c|c|c|c|}
\hline \multirow{2}{*}{ Kategori } & \multirow{2}{*}{$\begin{array}{c}\text { Interval } \\
\text { Skor }\end{array}$} & \multicolumn{2}{c|}{ Kondisi Awal } & \multicolumn{2}{c|}{$\begin{array}{c}\text { Setelah } \\
\text { Tindakan }\end{array}$} \\
\cline { 5 - 7 } & & F & $\%$ & f & $\%$ \\
\hline Baik Sekali & $91-100$ & & & 4 & 31 \\
\hline Baik & $76-90$ & 3 & 23 & 6 & 46 \\
\hline Cukup & $61-75$ & 5 & 38,5 & 3 & 23 \\
\hline Kurang & $51-60$ & 5 & 38,5 & & \\
\hline Kurang Sekali & $<50$ & & & & \\
\hline Total & & 13 & $100 \%$ & 13 & $100 \%$ \\
\hline
\end{tabular}


Dari tabel 2terlihat bahwa kompetensi penyusunan administrasi penilaian pembelajaran mengalami peningkatan. Terlihat sudah tidak ada guru yang tidak melaksanakan penilaian afektif, sudah melaksanakan tugas secara tertruktur, sudah melaksanakan program dan pelaksanaan remidial serta sudah melakukan analisis hasil ulangan, ada 4guru (31\%) pada kategori baik sekali, 6 guru (46\%) berada pada kategori baik dan 3 guru (23\%) berada pada kategori cukup.

\section{Keberhasilan supervisi akademik dalam meningkatkan bahwa kompetensi penyusunan administrasi penilaian pembelajaran}

Data pada tabel 1mengenai kompetensi guru pada kondisi awal dan tindakan menunjukkan temuan skor kemampuan guru dalam penyusunan administrasi penilaian pembelajaran kondisi awal 63,5 pada tindakan 89,6.Temuan ini mengindikasikan adanya peningkatan tingkat kemampuan guru dalam penyusunan administrasi penilaian pembelajaran. Besaran peningkatan 26,2\%. Jika dibandingkan dengan indikator kinerja $25 \%$ ternyata temuan tersebut telah mencapai keberhasilan. Temuan ini sejalan dengan penelitian Parwati Santi dkk (2013), Dalawi dkk (2012), dan Banun Sri Haksasi (2013).

\section{KESIMPULAN}

Berdasarkan hasil penelitian dan pembahasan, dapat disimpulkan bahwa supervisi akademik dapat: Meningkakan kemampuan guru dalam penyusunan administrasi penilaian pembelajarandi UPTD SDN Tamberu Timur sebesar 26,2\%.

\section{DAFTAR PUSTAKA}

Arikunto, Suharsimi. (2006). Dasar-Dasar Supervisi. Jakarta: Rineka Cipta

Danim Sudarwan dan Khairil. (2011). Profesi Kependidikan. Bandung: Alfabeta.

Daryanto dan Tasrial. (2011). Konsep Pembelajaran Kreatif. Yogyakarta: Gavamedia.

Sahertian, P.A .(2010). Konsep Dasar dan Teknik Supervisi Pendidikan dalam Rangka

Pengembangan Sumber Daya Manusia. Jakarta: Rineka Cipta.

Daryanto. (2010). Administrasi Pendidikan. Jakarta: Rineka Cipta.

Dirjen peningkatan mutu pendidikan dan tenaga kependidikan.2012. Pedoman

Pelaksanaan Kinerja Guru (PK Guru). Buku 2. Jakarta: kementerian Pendidikan dan

Kebudayaan.

Pujiono. (2014). Laporan Pelaksanaan Supervisi Akademik. SD Kristen Satya Wacana. 
Fodden

Penerapan Supervisi Akademilh untule meninghathan Kompetensi Gura dalam Menyusun Administrasi Peniliaian di UPTD SDN Tambera Timar Kecamatan Sahobanah Kabupaten Sampang

Sudjana Nana dkk. 2011. Buku Kerja Pengawas Sekolah. Pusat Pengembangan Tenaga Kependidikan, BadanPSDMdanPMP. Jakarta: Kementerian Pendidikan dan Kebudayaan

Suhertian, (2000). Konsep Dasar dan Teknik Supervisi Pendidikan.Jakarta: Rineka Cipta .(2009). Undang-Undang Nomor 39 tahun 2009 Tentang pemenuhan Beban Kerja Guru dan Pengawas Satuan Pendidikan. Jakarta (2005). Undang-Undang RI No. 14 Th. 2005 Tentang Guru dan Dosen.Jakarta:Depdiknas. (2007). Peraturan Menteri Pendidikan Nasional No. 16 Tahun 2007 tentang Standar Kompetensi Guru. Jakarta:Depdiknas. 